\title{
The most dangerous woman in the world?
}

"Psychotic human garbage full of putrid corruption, lies, conspiracy and total censorship" is not how Judith Mackay was introduced at this year's American College of Chest Physicians (ACCP) meeting, where she was awarded one of two World Health Organization (WHO) prizes. But it is how she was referred to by an American smokers' rights group in 1993. The reason is that Mackay is almost single-handedly responsible for introducing tobacco control legislation into Asia.

At the ACCP ceremony, Mackay also became one of the first recipients of funding from the recently established

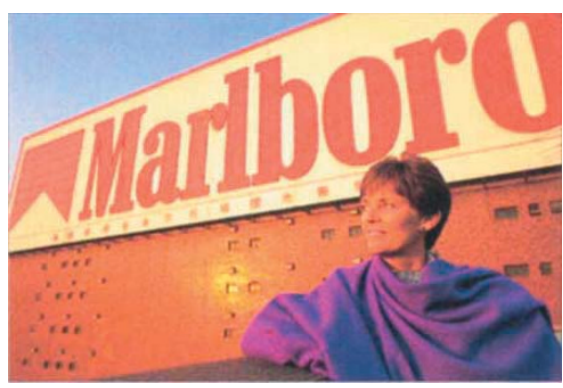

Professor judith Mackay could ride the Marlboro horse right into Asia with very little opposition. They thought they had 30-40 years before people started to adopt tobacco control measures," she explains, "but the expertise and experience of the West has been rapidly and expertly put into place."

In fact, Asia can lay claim to the best country in the world for tobacco control policy: Singapore has raised the price of cigarettes significantly, no-smoking areas are widespread, advertising or sponsorship is banned and the county has the lowest smoking rate in the world (17 percent). But Asia also has the She received $\$ 15,000$ to run a workshop on tobacco control initiatives involving chest physicians from Asian countries. That money is extremely important to Mackay because she has no organizational funding for her work. She now has to select a country somewhere between Mongolia and Indonesia for the 1998 workshop.

Mackay - a British physician who has worked in Hong Kong for 30 years and is one of the few non-Americans to have received the US Surgeon General's Medallion-left clinical medicine in 1984 when she realized that her work was a Band-Aid measure. "We never seemed to admit a non-smoker," she remembers, "all lung cancer cases die. I wanted to go further up the river and stop all these folks falling in."

She took on the role of assisting Asian countries in drafting tobacco control legislation and countering the transnational tobacco companies in the region. She has been so successful that those companies describe her as one of the three most dangerous people in the world-the other two are men. She is constantly challenged by them during TV and radio interviews, filmed and recorded when she makes speeches and often threatened personally with legal action.

"The tobacco companies thought they worst country-one in every three cigarettes smoked in the world is smoked in China; there are 300 million Chinese smokers, which is more than the entire US population. Currently, the biggest tobacco company in the world is the Chinese government and most Chinese smoke the national cigarettes. Now foreign companies are penetrating China by signing joint ventures with national tobacco companies and Mackay predicts that a takeover similar to that in Eastern Europe, South America, India and Africa is simpiy a matter of time.

Although China has introduced advertising bans and health warnings, it has become increasingly difficult to get any legislation passed in recent years because of tobacco company pressure. They are quick to bring in executives and lawyers to threaten governments with court action on the grounds that sales and advertising bans contravene international covenants for freedom rights. "The fierceness of their attack is because they see Asia as their future," explains Mackay. "They have said that thinking about Chinese smoking statistics is like thinking about the limits of outer space and that it wouldn't matter if everybody in North America stopped smoking tomorrow if they could capture the Asian market."
Tobacco companies also lobby Asian governments with the help of foreign embassies (US, UK and Japan). "The latest example is Taiwan," reveals Mackay, "where companies have indicated that if Taiwan passes certain tobacco control laws, then America will not support their efforts to join the World Trade Organization."

But Mackay has been successful in extending legislation in Hong Kong. At two minutes to midnight on the day that Hong Kong was returned to Chinese rule, she won the right to prevent cigarette advertising in print media and outdoors, and to ban smoking in restaurants that seat 200 people or more. Hong Kong is also notable for the high price of its cigarettes-the Financial Secretary raised the price to US\$3.5 per pack, stating that the increased tax was for health as well as for fiscal reasons.

Despite Mackay's victories-two thirds of Asia now has tobacco control legislation in place-her keynote closing speech at the 10th World Conference on Tobacco and Health in Beijing this August was alarming. "There are 1.1 billion smokers in the world, and by 2025 we will have 1.64 billion. This translates into 3 million deaths today and 10 million by 2025 . The reason that we'll have half as many smokers again is that there will be more people in the world, people are living longer and more women in developing countries will begin smoking. So, in spite of all our efforts, we are currently losing the epidemic."

Nevertheless, pressure from the tobacco giants sustains Mackay in her campaign. "The legacy I would like to leave," she says, "is that all countries have a sound tobacco control legislation. I'm working with the WHO to try and establish a tobacco advertising free Asia by the year 2000."

A comparative unknown in the US before the ACCP award, Mackay has been concerned with the fireceness of the tobacco establishment's attacks on her and says that increasing her public profile is like taking out life insurance. "I repeatedly tell my lawyers, friends and colleagues that I'm not in the habit of disappearing suddenly," jokes Mackay.

KAREN BIRMINGHAM 